ACTA UNIVERSITATIS NICOLA I C P ER NICI

EKONOMIA XLIII nr 1 (2012)

\title{
Hanna Karaszewska* \\ WYNAGRODZENIE GIGANTÓW POLSKIEJ GOSPODARKI PO AKCESJI DO UE
}

Z a r y s t r e ś c i . Artykuł zawiera wyniki analizy zmian, które dokonały się w sferze płac, $w$ tym ich powiązania $z$ poziomem rentowności największych przedsiębiorstw w Polsce po akcesji. Trendy dotyczące zmian strukturalnych definiowane są z uwzględnieniem przekroju według sekcji, form własności, udziału kapitału zagranicznego.

S ł o w a k 1 u c z o w e : płace, wynagrodzenia, relacje płac, zróżnicowanie płac, wyniki ekonomiczne, akcesja do UE.

\section{WSTĘP}

Dokonywanie analiz płac w ich realnej warstwie jest niezwykle trudne i tworzy jedynie przybliżony obraz rzeczywistości. Statystyki państwowe operują kategoriami o dużym stopniu agregacji. Obarczone są ponadto niedoskonałościami, będącymi skutkiem funkcjonowania w płacach szarej strefy, ułomnościami statystyki kosztów pracy i wynagrodzeń w przedsiębiorstwach, efektem zmienności metodologii badań płac. Zwłaszcza ta ostatnia kwestia sprawia, że trudno tu zidentyfikować długofalowe trendy. Od wielu wspomnianych ograniczeń nie są wolne również statystyki międzynarodowe. Warto w tym miejsce przytoczyć EUROSTAT, w którym dane o płacach są niezwykle skąpe, a układy, w których są one prezentowane, podlegają ciagłym zmianom.

* Adres do korespondencji: Hanna Karaszewska, Uniwersytet Mikołaja Kopernika, WNEiZ, ul. Gagarina 13A, 87-100 Toruń, e-mail: hankar@econ.uni.torun.pl.

(C) 2012 Wydawnictwo Naukowe Uniwersytetu Mikołaja Kopernika. All rights reserved. http://www.aunc.ekonomia.umk.pl 
Komplementarnym źródłem wiedzy o płacach są informacje uzyskiwane przez firmy konsultingowe $\mathrm{w}$ ramach rynkowych przeglądów wynagrodzeń. Pokazują one rzeczywistość znacznie mniej zagregowaną. Są jednak wciąż wyrywkowe i nie dają podstaw do uogólnien. W tej sytuacji nieocenionym źródłem informacji na temat kształtowania się wysokości płac i ich relacji stają się rankingi podmiotów gospodarczych, przeprowadzane na podstawie różnych kryteriów. Mimo że pokazują one wyodrębniony fragment rzeczywistości, pozwalają jednak na śledzenie zmian w płacach $\mathrm{w}$ ich konkretnych uwarunkowaniach i współzależnościach. Jest sprawą oczywista, że jakość uzyskanych informacji zależy od profesjonalizmu ich przygotowania.

\section{CELE BADANIA I JEGO METODYKA} było:

Celem badania, którego rezultaty zaprezentowane zostaną w artykule,

a) zdefiniowanie podstawowych cech struktury oraz zmian $w$ niej zachodzących w największych polskich przedsiębiorstwach $\mathrm{z}$ uwzględnieniem kryterium rodzaju prowadzonej działalności, sektora gospodarki, udziału kapitału zagranicznego;

b) sformułowanie tendencji zmian w kształtowaniu się płac i ich zróżnicowaniu $\mathrm{w}$ największych podmiotach gospodarczych $\mathrm{w}$ Polsce po akcesji do UE;

c) określenie związku płac $\mathrm{z}$ wynikami ekonomicznymi największych przedsiębiorstw w Polsce przed akcesją i po niej.

Materiałem źródłowym, na podstawie którego przeprowadzono analizę, były dane zawarte na Liście 500 największych pod względem poziomu przychodów podmiotów funkcjonujących na polskim rynku, publikowane przez dziennik „Rzeczpospolita” w latach 2004, 2006, 2008, 2010.

Analiza obejmuje rok 2003 (przed akcesją do UE) oraz lata 2005, 2007, 2009.

\section{PREZENTACJA BADANEJ ZBIOROWOŚCI}

W analizowanym okresie wyraźnie słabnie skłonność przedsiębiorstw znajdujących się na Liście 500 do udostępniania swoich danych o płacach. W roku 2010 ich udział w całej zbiorowości wynosił jedynie 47,2\%. Stanowiły one przy tym $80 \%$ grupy, która przekazała informacje o wynagrodzeniach w roku 2003. Prezentacja firm ,pięćsetki” zawarta w tabeli 1 ogranicza się do tych, które podały dane o płacach. 
Tabela 1. Przedsiębiorstwa z Listy 500 według formy własności w latach 2003, 2005, 2007, 2009

\begin{tabular}{|c|c|c|c|c|c|c|c|c|}
\hline \multirow[b]{2}{*}{ Forma własności } & \multicolumn{2}{|c|}{2003} & \multicolumn{2}{|c|}{2005} & \multicolumn{2}{|c|}{2007} & \multicolumn{2}{|c|}{2009} \\
\hline & liczba & $\begin{array}{c}\text { udział } \\
(\%)\end{array}$ & liczba & $\begin{array}{c}\text { udział } \\
(\%)\end{array}$ & liczba & $\begin{array}{c}\text { udział } \\
(\%)\end{array}$ & liczba & $\begin{array}{c}\text { udział } \\
(\%)\end{array}$ \\
\hline Spółki Skarbu Państwa & 76 & 25,8 & 48 & 16,8 & 32 & 13,9 & 26 & 11,0 \\
\hline Spółki z udziałem zagranicznym & 2 & 0,7 & 1 & 0,4 & 2 & 0,9 & 2 & 8,5 \\
\hline Przedsiębiorstwa państwowe, & 24 & 8,1 & 27 & 9,5 & 15 & 6,5 & 10 & 4,2 \\
\hline w tym: z udziałem zagranicznym & - & - & - & - & 3 & 1,3 & 1 & 0,4 \\
\hline Przedsiębiorstwa komunalne & 2 & 0,7 & 6 & 2,1 & 3 & 1,3 & 5 & 2,1 \\
\hline $\begin{array}{l}\text { Przedsiębiorstwa prywatne } \\
\text { z większościowym i pełnym } \\
\text { udziałem kapitału polskiego }\end{array}$ & 67 & 22,7 & 88 & 30,9 & 85 & 36,8 & 85 & 36,0 \\
\hline $\begin{array}{l}\text { Przedsiębiorstwa prywatne } \\
\text { z mniejszościowym udziałem } \\
\text { kapitału zagranicznego }\end{array}$ & 12 & 4,1 & 12 & 4,2 & 10 & 4,3 & 13 & 5,5 \\
\hline $\begin{array}{l}\text { Przedsiębiorstwa z większościo- } \\
\text { wym i pełnym udziałem kapitału } \\
\text { zagranicznego }\end{array}$ & 126 & 42,7 & 116 & 40,7 & 96 & 41,6 & 110 & 46,6 \\
\hline Ogółem & 295 & 100,0 & 285 & 100,0 & 231 & 100,0 & 236 & 100,0 \\
\hline
\end{tabular}

Źródło: opracowanie własne na podstawie: Lista 500, „Rzeczpospolita”, kwiecień 2004; Lista 500, „Rzeczpospolita”, kwiecień 2006; Lista 500, „Rzeczpospolita”, kwiecień 2008; Lista 500, „Rzeczpospolita”, kwiecień 2010.

W analizowanym okresie wśród podmiotów wymienionych na Liście dwukrotnie zmalał udział przedsiębiorstw należących do sektora publicznego. O ile w roku 2003 stanowiły one 34,6\% ogólnej ich liczby, to w 2009 już tylko $17,3 \%$. Jeśli do powyższego dodać, że skłonność do utajniania informacji o wynagrodzeniach cechuje zwłaszcza sektor prywatny, jego przewaga pod względem liczebności reprezentacji wśród prezentowanych gigantów staje się większa. Pomimo powyższych procesów udział przedsiębiorstw sektora publicznego na Liście wyższy niż analogiczny w całym sektorze przedsiębiorstw nadaje rankingowi wyraźną specyfikę.

Konsekwencją postępującego napływu kapitału zagranicznego było umocnienie się na pozycji lidera pod względem liczebności reprezentacji podmiotów zagranicznych. Stanowiły one w roku 2003, łącznie z nieobjętymi w tabeli 1 przedsiębiorstwami, które nie przekazały informacji o wynagrodzeniach, zbiorowość liczącą 275 podmiotów (55\% ogółu). Sześć lat później ich przedstawicielstwo liczyło już 309 przedsiębiorstw $(61,5 \%)$. 
Relatywnie liczniejszą (aż o 14 p.p.) $)^{1}$ grupę podmiotów gospodarczych w Polsce wśród ,pięćsetki" stanowią przedsiębiorstwa przemysłowe. Stosunkowo większe przedstawicielstwo niż w całym sektorze przedsiębiorstw mają na Liście 500 firmy sektora finansowego. Jednakże ich skłonność do przekazywania danych o płacach systematycznie maleje.

Od początku prowadzenia rankingu przedsiębiorstwami o małej skłonności do przekazywania informacji o płacach były te, które reprezentują działalność handlową. Jeśli uzupełnić tabelę 2 o nieobecne $\mathrm{z}$ tego powodu 33 podmioty (w roku 2009), to daje się zauważyć znacznie większy ich udział wśród gigantów niż w ogóle podmiotów firm w Polsce.

Tabela 2. Przedsiębiorstwa Listy 500 wedhug sekcji w latach 2003, 2005, 2007, 2009

\begin{tabular}{|c|c|c|c|c|c|c|c|c|}
\hline \multirow{2}{*}{ Sekcja } & \multicolumn{2}{|c|}{2003} & \multicolumn{2}{|c|}{2005} & \multicolumn{2}{|c|}{2007} & \multicolumn{2}{|c|}{2009} \\
\hline & liczba & $\%$ & liczba & $\%$ & liczba & $\%$ & liczba & $\%$ \\
\hline Rolnictwo i leśnictwo (A) & 1 & 0,3 & 1 & 0,4 & 1 & 0,4 & - & - \\
\hline Górnictwo i kopalnictwo (C) & 9 & 3,1 & 9 & 3,2 & 6 & 2,6 & 4 & 1,7 \\
\hline Działalność produkcyjna (D) & 115 & 39,0 & 118 & 41,4 & 92 & 39,8 & 105 & 44,5 \\
\hline $\begin{array}{l}\text { Zaopatrywanie w energię elektryczną, } \\
\text { gaz i wodę }(E)\end{array}$ & 53 & 18,0 & 35 & 12,3 & 17 & 7,4 & 12 & 5,1 \\
\hline Budownictwo (F) & 5 & 1,7 & 5 & 0,7 & 9 & 3,9 & 12 & 5,1 \\
\hline Handel hurtowy i detaliczny (G) & 81 & 27,5 & 71 & 24,9 & 69 & 29,9 & 71 & 30,1 \\
\hline Hotele i restauracje & - & - & 2 & 0,7 & 2 & 0,9 & - & - \\
\hline Transport i łączność (I) & 1 & 0,3 & 22 & 7,7 & 19 & 8,2 & 16 & 6,8 \\
\hline Pośrednictwo finansowe (J) & 15 & 5,1 & 6 & 2,1 & 3 & 1,3 & 5 & 2,1 \\
\hline Obsługa nieruchomości i wynajem (K) & 7 & 2,4 & 9 & 3,2 & 6 & 2,6 & 4 & 1,7 \\
\hline Pozostała działalność usługowa $(\mathrm{P})$ & 4 & 1,4 & 7 & 2,5 & 7 & 3,0 & 7 & 3,0 \\
\hline Działalność zdywersyfikowana (Zd) & 4 & 1,4 & - & - & - & - & - & - \\
\hline
\end{tabular}

Źródło: jak w tabeli 1.

Kryterium, na podstawie którego sporządzony został ranking, determinuje specyficzną strukturę podmiotów według wielkości zatrudnienia. W porównaniu z rokiem 2003 reprezentacja MŚP (16\% ogółu podmiotów Listy) zmniejszyła się o 6 p.p.

\footnotetext{
${ }^{1}$ Z danych GUS wynika, że w 2009 roku reprezentacja sekcji przetwórstwo przemysłowe stanowiła 30,9\% ogółu podmiotów gospodarczych w Polsce, a sekcji handel hurtowy i detaliczny $-27,8 \%$.
} 


\section{POZIOM I RELACJE PŁAC A WYNIKI FINANSOWE}

W badanym okresie płace w przedsiębiorstwach Listy 500 wzrosły o 44 pkt proc. W tym samym czasie przedsiębiorstwa zanotowały wyraźny wzrost wyników finansowych, mierzonych wskaźnikiem rentowności brutto. Interesujące jest, że wzrost płac w latach późniejszych był znacznie bardziej dynamiczny (w roku 2007 wzrosły one o ok. 13 pkt proc., a w 2009 aż o ok. 20 pkt proc.) niż w rok po akcesji (w roku 2005 o 6 pkt proc. w stosunku do roku 2003), pomimo iż lata wcześniejsze to dla przedsiębiorstw z Listy zdecydowanie lepszy okres, gdy chodzi o wzrost wyników finansowych (w roku 2005 w stosunku do roku 2003 wskaźnik rentowności brutto wzrósł o 22 p.p., a jego wzrost w roku 2009 w stosunku do roku 2005 wyniósł tylko 13 p.p.). Fakt ten dowodzi, że samo wejście w struktury UE nie spowodowało gwałtownego nacisku na płace.

Sekcją wiodącą $\mathrm{w}$ rankingu według średniej płacy było wśród przedsiębiorstw ,pięćsetki” w 2003 i 2005 roku górnictwo i kopalnictwo ${ }^{2}$. Co prawda w 2003 i 2009 roku wyniki finansowe podmiotów lokujących się w tej sekcji były relatywnie wysokie, ale dla przykładu w roku 2007 wskaźnik rentowności brutto spadł drastycznie, stanowiąc jedynie $13,7 \%$ poziomu analogicznego dla całej „pięćsetki”, natomiast płace nie uległy zmianie. Przewaga przedsiębiorstw tego segmentu działalności na Liście była jednak znacznie mniejsza aniżeli przedsiębiorstw analogicznych w całym sektorze.

Boom budowlany, połączony z migracją pracowników budowlanych, wywindował w roku 2007 płace w sekcji budownictwo do maksymalnego w badanym okresie poziomu przekraczającego o 50 p.p. wynagrodzenia w ,pięćsetce". W tym samym czasie znacznie poprawily się wyniki finansowe tej sekcji (wskaźnik rentowności brutto wzrósł w roku 2007 w stosunku do roku 2005 aż 6-krotnie), chociaż i tak poziom rentowności przedsiębiorstw tej sekcji był prawie dwukrotnie niższy niż ogółu podmiotów z Listy. Chociaż w roku 2009 płace w budownictwie spadły o ok. 6 p.p., to i tak sekcja ta utrzymała pozycję lidera ${ }^{3}$. Nie bez wpływu na to miała specyfika struktury własnościowej podmiotów tej sekcji. Przeważały w nich spółki z udziałem zagranicznym, o relatywnie wysokim poziomie wynagrodzeń i lepszych wynikach finansowych.

\footnotetext{
${ }^{2}$ Sekcje hotele i restauracje, obsługa nieruchomości, wynajem i działalność związana z robieniem interesów oraz pozostała działalność usługowa ze względu na to, że reprezentowane są przez liczące kilka podmiotów zbiorowości, zostały w analizie pominięte.

3 Trzeba przy tym pamiętać, że podmioty sekcji pośrednictwo finansowe w znikomym stopniu udostępniają swoje dane o płacach. Fakt ten w sposób oczywisty zamazuje obraz relacji płac.
} 
Gorsza w porównaniu z pozycją w całym sektorze przedsiębiorstw w Polsce była w roku bazowym pozycja w płacowej hierarchii przedsiębiorstw reprezentujących na Liście zaopatrywanie w energię elektryczna, gaz i wodę. Bardzo dynamiczny wzrost (zwłaszcza w roku 2007) wynagrodzeń pracowników tego segmentu doprowadził do poprawy miejsca tej sekcji w rankingu. Jednak wyraźnie słabnąca, pomimo ogromnej poprawy wyników finansowych (wskaźnik rentowności brutto wzrósł ponad dwukrotnie - tabela 1), dynamika wzrostu spowodowała, że płace przedsiębiorstw tej sekcji tylko o ok. 5 p.p. przewyższały wynagrodzenia w całej ,,pięćsetce”.

Podobnie dają się zdefiniować odmienności w płacach właściwe przedsiębiorstwom świadczącym usługi w dziedzinie transportu i łączności. Słaba kondycja płacowa państwowych molochów, takich jak Polskie Koleje Państwowe, Poczta Polska, generowała najgorsze miejsce w rankingu wynagrodzeń zbiorowości reprezentującej tę sekcję na Liście. Trzeba jednak podkreślić, że przedsiębiorstwa analizowanej sekcji z roku na rok poprawiały swoje wyniki finansowe. Wyraźnie gorzej radziły sobie również w ostatnim okresie przedsiębiorstwa przemysłowe (tabele 3, 4).

Tabela 3. Rentowność brutto w przedsiębiorstwach z Listy 500 według sekcji w latach 2003, 2005, 2007, 2009

\begin{tabular}{|c|c|c|c|c|}
\hline Sekcja & 2003 & 2005 & 2007 & 2009 \\
\hline C & 10,3 & 7,8 & 0,85 & 10,5 \\
D & 5,1 & 6,3 & 6,1 & 5,3 \\
E & 2,9 & 6,4 & 8,1 & 17,6 \\
F & 2,3 & 0,6 & 3,7 & 5,8 \\
G & 2,2 & 1,4 & 1,0 & 2,2 \\
I & 6,3 & 9,7 & 11,8 & 12,9 \\
J & 20,1 & 8,9 & 10,7 & 12,3 \\
\hline Ogółem & 4,9 & 6,0 & 6,3 & 6,8 \\
\hline
\end{tabular}

Źródło: jak w tabeli 1.

W roku bazowym przedsiębiorstwa z Listy 500 sytuujące się w sektorze publicznym charakteryzował niższy poziom przeciętnych wynagrodzeń aniżeli podmiotów sektora prywatnego (tabele 5,6 ). Lata kolejne przyniosły zdecydowaną $\mathrm{w}$ tym zakresie zmianę. Wyraźnie zwiększał się dystans między przedsiębiorstwami obu analizowanych sektorów, na korzyść sektora publicznego. W stosunku do roku 2007 płace w tym sektorze wzrosły w stosunku do roku 2005 o 22 p.p., przy czym największy przyrost zanotowały spółki Skarbu Państwa. W tym samym czasie podmioty sektora prywatnego zareagowały 
spadkiem poziomu płac o ok. 4 p.p. Spadek ten wynikał z wyraźnego obniżenia płac $\mathrm{w}$ przedsiębiorstwach $\mathrm{z}$ pełnym lub większościowym udziałem kapitału polskiego. Przedsiębiorstwa $\mathrm{z}$ większościowym i pełnym udziałem kapitału zagranicznego z pozycji środkowej wśród przedsiębiorstw prywatnych przesunęły się już w roku 2007 na pozycję lidera płacowego, co wyraźnie korespondowało $\mathrm{z}$ ich wynikami finansowymi (wskaźnik rentowności brutto wzrósł o około 18 p.p. w stosunku do roku 2005). Przeciętne wynagrodzenia w tych podmiotach przewyższały średnią płacę w całej „pięćsetce” o około 11 p.p., ale - co należy podkreślić - były w roku 2009 prawie tożsame z płacami w spółkach Skarbu Państwa. Solidny środek przypadł podmiotom $\mathrm{z}$ mniejszościowym udziałem kapitału zagranicznego, które $\mathrm{w}$ rok przed akcesją i rok po niej zajmowały pozycję wiodącą w rankingu średniej płacy. Osiaggały one w tym czasie najlepsze wyniki finansowe wśród ogółu przedsiębiorstw z Listy 500 (rentowność obrotu brutto analizowanych podmiotów w roku 2005 była ponad dwukrotnie wyższa niż dla przykłady spółek Skarbu Państwa).

Tabela 4. Płace w przedsiębiorstwach z Listy 500 według sekcji w latach 2003, 2005, 2007, 2009

\begin{tabular}{|c|c|c|c|c|c|c|c|c|}
\hline \multirow[b]{2}{*}{ Sekcja } & \multicolumn{2}{|r|}{2003} & \multicolumn{2}{|r|}{2005} & \multicolumn{2}{|r|}{2007} & \multicolumn{2}{|r|}{2009} \\
\hline & (w zł) & \begin{tabular}{|c|} 
w relacji do \\
płacy prze- \\
ciętnej ogółu \\
podmiotów \\
z Listy 500 \\
$(\%)$
\end{tabular} & (w z z $)$ & $\begin{array}{c}\text { w relacji do } \\
\text { płacy prze- } \\
\text { ciętnej ogółu } \\
\text { podmiotów } \\
\text { z Listy } 500 \\
(\%)\end{array}$ & $(w z ł)$ & \begin{tabular}{|c|} 
w relacji do \\
płacy prze- \\
ciętnej ogółu \\
podmiotów \\
z Listy 500 \\
$(\%)$
\end{tabular} & (w zł) & $\begin{array}{c}\text { w relacji do } \\
\text { płacy prze- } \\
\text { ciętnej ogółu } \\
\text { podmiotów } \\
\text { z Listy } 500 \\
(\%)\end{array}$ \\
\hline$C$ & 4043 & 120,0 & 4245 & 118,9 & 4769 & 118,5 & 5838 & 120,5 \\
\hline$D$ & 3077 & 91,3 & 3101 & 86,9 & 4523 & 112,4 & 4651 & 96,0 \\
\hline$E$ & 3495 & 103,7 & 4006 & 112,2 & 5078 & 126,2 & 5091 & 105,1 \\
\hline$F$ & 3265 & 96,9 & 3107 & 87,0 & 6265 & 155,7 & 5925 & 122,3 \\
\hline G & 3312 & 98,3 & 3767 & 105,5 & 4407 & 109,5 & 4189 & 86,5 \\
\hline I & 2555 & 75,8 & 3384 & 94,8 & 3364 & 83,6 & 4421 & 91,3 \\
\hline $\mathrm{J}$ & 3712 & 110,2 & 5010 & 140,0 & 4651 & 115,6 & 4814 & 99,4 \\
\hline Ogółem & 3369 & 100,0 & 3569 & 100,0 & 4025 & 100,0 & 4844 & 100,0 \\
\hline
\end{tabular}

Źródło: jak w tabeli 1.

Relacje płac $\mathrm{w}$ przedsiębiorstwach analizowanych $\mathrm{w}$ przekroju sektorów własności nie pozostawały do roku 2007 w związku z relacją wskaźnika rentowności brutto (tabele 7,8 ). Wprawdzie podmioty sektora publicznego notowały w analizowanym okresie systematyczny wzrost tego wskaźnika 


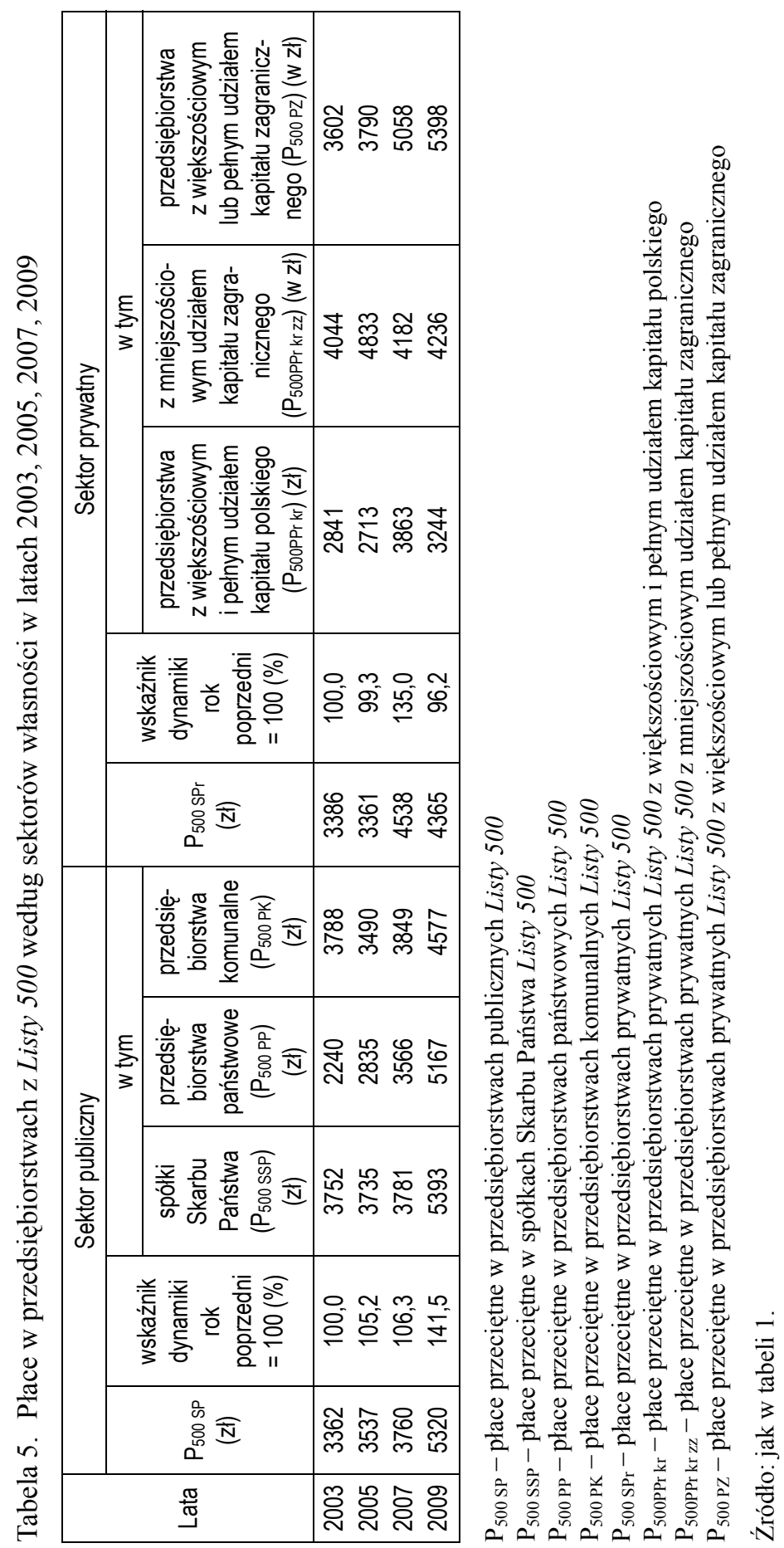


(najbardziej dynamiczny w roku 2009), ale i tak aż do roku 2007 wskaźnik ten był niższy niż w przedsiębiorstwach z Listy 500 reprezentujących sektor prywatny. Warto przy tym zaznaczyć, że tak hojnie opłacające swoich pracowników spółki Skarbu Państwa spośród ogółu podmiotów sektora publicznego odnotowały w roku 2009 najniższy wskaźnik rentowności (trzykrotnie niższy niż np. przedsiębiorstwa państwowe i o 30 p.p. niższy niż przedsiębiorstwa prywatne z mniejszościowym udziałem kapitału zagranicznego o płacy niższej o ponad 20 p.p.).

Tabela 6. Relacje płac wewnątrz sektorów własności w przedsiębiorstwach Listy 500 w latach 2003, 2005, 2007, 2009

\begin{tabular}{|c|c|c|c|c|c|c|c|}
\hline Lata & $\begin{array}{l}P_{500 S P} / \\
/ P_{500 \mathrm{SPr}}\end{array}$ & $\begin{array}{l}P_{500 s s p} / \\
/ P_{500}\end{array}$ & $\begin{array}{c}\mathrm{P}_{5000 \mathrm{PP}} / \\
/ \mathrm{P}_{500}\end{array}$ & $\begin{array}{l}\mathrm{P}_{5000 \mathrm{PK}} / \\
/ \mathrm{P}_{500}\end{array}$ & $\begin{array}{c}\mathrm{P}_{500 \mathrm{PPr} \mathrm{kr}} / \mathrm{f} \\
/ \mathrm{P}_{500}\end{array}$ & $\begin{array}{c}\text { P500PPr kr zzl } \\
\quad \mathrm{P}_{500}\end{array}$ & $\begin{array}{c}\mathrm{P}_{500 \mathrm{PZ}} / \\
\mid \mathrm{P}_{500}\end{array}$ \\
\hline 2003 & 99,3 & 99,8 & 66,5 & 112,4 & 84,3 & 120,0 & 106,9 \\
\hline 2005 & 105,2 & 104,7 & 79,4 & 97,8 & 76,0 & 135,4 & 106,2 \\
\hline 2007 & 117,2 & 100,6 & 94,8 & 102,4 & 102,7 & 111,2 & 134,5 \\
\hline 2009 & 121,9 & 111,3 & 106,7 & 94,5 & 67,0 & 87,4 & 111,4 \\
\hline
\end{tabular}

Źródło: jak w tabeli 1.

Tabela 7. Rentowność obrotu brutto w przedsiębiorstwach Listy 500 według form własności w latach 2003, 2005, 2007, 2009

\begin{tabular}{|c|c|c|c|c|c|c|c|c|}
\hline \multirow[b]{2}{*}{ Lata } & \multirow[b]{2}{*}{$\begin{array}{c}\text { Przedsię- } \\
\text { biorstwa } \\
\text { z Listy } \\
500 \\
\text { (R500 SP) }\end{array}$} & \multicolumn{3}{|c|}{ W tym: } & \multirow[b]{2}{*}{$\begin{array}{c}\text { Przedsię- } \\
\text { biorstwa } \\
\text { z Listy } \\
500 \\
\text { (R500 SPr) }\end{array}$} & \multicolumn{3}{|c|}{ W tym: } \\
\hline & & $\begin{array}{c}\text { spółki } \\
\text { Skarbu } \\
\text { Państwa } \\
\text { (R500 ssP) }\end{array}$ & $\begin{array}{c}\text { przedsię- } \\
\text { biorstwa } \\
\text { pań- } \\
\text { stwowe } \\
\text { (R500 PP) }\end{array}$ & $\begin{array}{c}\text { przed- } \\
\text { siębior- } \\
\text { stwa } \\
\text { komu- } \\
\text { nalne } \\
\text { (R500 PK) }\end{array}$ & & $\begin{array}{l}\text { przedsiębior- } \\
\text { stwa z więk- } \\
\text { szościowym } \\
\text { i pełnym } \\
\text { udziałem } \\
\text { kapitału } \\
\text { polskiego } \\
\text { (R500PPr kr) }\end{array}$ & $\begin{array}{l}\text { przedsię- } \\
\text { biorstwa } \\
\text { z mniejszo- } \\
\text { ściowym } \\
\text { udziałem } \\
\text { kapitału za- } \\
\text { granicznego } \\
\text { (R500PPr kr zz) }\end{array}$ & $\begin{array}{l}\text { przedsiębior- } \\
\text { stwa z pełnym } \\
\text { lub większo- } \\
\text { ściowym } \\
\text { udziałem } \\
\text { kapitału } \\
\text { zagranicznego } \\
\text { (R500 Pz) }\end{array}$ \\
\hline 2003 & 4,9 & 5,1 & 4,2 & 2,2 & 4,9 & 4,5 & 8,5 & 5,1 \\
\hline 2005 & 5,5 & 6,5 & 1,6 & 1,9 & 6,4 & 4,5 & 14,7 & 7,2 \\
\hline 2007 & 6,0 & 5,4 & 8,6 & 2,5 & 6,3 & 4,2 & 8,7 & 8,5 \\
\hline 2009 & 6,9 & 5,1 & 15,4 & 6,4 & 6,8 & 4,3 & 6,7 & 8,3 \\
\hline
\end{tabular}

$\mathrm{R}_{500 \mathrm{SP}}$ - rentowność obrotu brutto w przedsiębiorstwach publicznych z Listy 500

$\mathrm{R}_{500}$ SSP - rentowność obrotu brutto w spółkach Skarbu Państwa z Listy 500

$\mathrm{R}_{500 \mathrm{PP}}$ - rentowność obrotu brutto w przedsiębiorstwach państwowych z Listy 500

$\mathrm{R}_{500 \text { PK }}$ - rentowność obrotu brutto w przedsiębiorstwach komunalnych z Listy 500

$\mathrm{R}_{500 \mathrm{SPr}}$ - rentowność obrotu brutto w przedsiębiorstwach prywatnych z Listy 500

$\mathrm{R}_{500 \mathrm{PPr} k \mathrm{kr}}$ - rentowność obrotu brutto w przedsiębiorstwach prywatnych z Listy $500 \mathrm{z}$ większo-

ściowym i pełnym udziałem kapitału polskiego 
$\mathrm{R}_{500 \mathrm{PPr} \mathrm{kr} \mathrm{zz}}$ - rentowność obrotu brutto w przedsiębiorstwach prywatnych z Listy 500 z mniejszościowym udziałem kapitału zagranicznego

$\mathrm{R}_{500 \mathrm{PZ}}$ - rentowność obrotu brutto w przedsiębiorstwach z Listy 500 z pełnym lub większościowym udziałem kapitału zagranicznego

Źródło: jak w tabeli 1.

Tabela 8. Relacje rentowności brutto wewnątrz sektorów własności w przedsiębiorstwach z Listy 500 w latach 2003, 2005, 2007, 2009

\begin{tabular}{|c|c|c|c|c|c|c|c|}
\hline \multirow[b]{2}{*}{ Lata } & \multicolumn{7}{|c|}{ Relacje } \\
\hline & 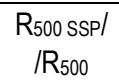 & $\begin{array}{l}R_{500 \mathrm{PP}} / \\
/ \mathrm{R}_{500}\end{array}$ & $\begin{array}{l}\mathrm{R}_{500 \mathrm{PK}} / \\
/ \mathrm{R}_{500}\end{array}$ & $\begin{array}{l}\mathrm{R}_{500 \mathrm{SPr}} / \\
/ \mathrm{R}_{500}\end{array}$ & $\begin{array}{c}\mathrm{R}_{500 \mathrm{PPr} \mathrm{kr}} / \\
/ \mathrm{R}_{500}\end{array}$ & 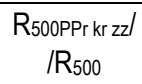 & $\begin{array}{c}\mathrm{R}_{500 \mathrm{PZ}} \mid \\
\mid \mathrm{R}_{500}\end{array}$ \\
\hline 2003 & 104,1 & 85,7 & 44,9 & 100,0 & 91,8 & 173,5 & 104,1 \\
\hline 2005 & 108,3 & 26,7 & 31,7 & 106,7 & 75,0 & 245,0 & 120,0 \\
\hline 2007 & 87,1 & 138,7 & 40,3 & 101,6 & 67,7 & 140,3 & 137,1 \\
\hline 2009 & 75,0 & 226,5 & 94,1 & 100,0 & 63,2 & 98,5 & 122,1 \\
\hline
\end{tabular}

Źródło: jak w tabeli 1.

Analizę opartą na wynagrodzeniach przeciętnych uzupełnia prezentacja rozkładu przedsiębiorstw „pięćsetki” według poziomu ich średniej płacy (tabela 9).

Tabela 9. Rozkład przedsiębiorstw z Listy 500 według poziomu średniej płacy w latach 2003, 2005, 2007, 2009

\begin{tabular}{|l|c|c|c|c|c|c|c|c|}
\hline \multirow{2}{*}{ Przedział płac w zł } & \multicolumn{2}{|c|}{2003} & \multicolumn{2}{c|}{2005} & \multicolumn{2}{c|}{2007} & \multicolumn{2}{c|}{2009} \\
\cline { 2 - 9 } & liczba & $\begin{array}{c}\text { udział } \\
(\%)\end{array}$ & liczba & $\begin{array}{c}\text { udział } \\
(\%)\end{array}$ & liczba & $\begin{array}{c}\text { udział } \\
(\%)\end{array}$ & liczba & $\begin{array}{c}\text { udział } \\
(\%)\end{array}$ \\
\hline Do 2000 & 28 & 9,4 & 29 & 10,2 & 7 & 3,0 & 8 & 3,4 \\
$2001-3000$ & 81 & 27,5 & 77 & 27,0 & 30 & 13,0 & 27 & 11,4 \\
$3001-4000$ & 77 & 26,1 & 66 & 23,2 & 48 & 20,8 & 45 & 19,1 \\
$4001-5000$ & 41 & 13,9 & 44 & 15,4 & 46 & 19,9 & 57 & 24,1 \\
$5001-6000$ & 29 & 9,8 & 19 & 6,7 & 30 & 13,0 & 36 & 15,3 \\
$6001-7000$ & 12 & 4,1 & 21 & 7,4 & 18 & 7,8 & 20 & 8,5 \\
$7001-8000$ & 9 & 3,1 & 14 & 4,9 & 18 & 7,8 & 15 & 6,4 \\
$8001-10000$ & 9 & 3,1 & 6 & 2,1 & 18 & 7,8 & 13 & 5,5 \\
Powyżej 10 000 & 9 & 3,1 & 9 & 3,2 & 16 & 6,9 & 20 & 8,5 \\
\hline Ogółem & 295 & 100,0 & 285 & 100,0 & 231 & 100,0 & 236 & 100,0 \\
\hline
\end{tabular}

Źródło: jak w tabeli 1.

Jeśli przyjać jako zbliżony do średniej poziom płac wyznaczony ramami 75-125, to okaże się, że w roku 2003 przedsiębiorstwa z Listy 500 zajmowały 
w większości właśnie ten przedział. Większość gigantów w roku 2009 sytuowało się w przedziale płac 4-5 tys., tj. wyższym od poziomu wyznaczonego płacą przeciętną. Przedziały płac relatywnie wysokich (powyżej 4 tys. zł w roku 2003 i powyżej 5 tys. w roku 2009) zajmowane były odpowiednio przez 37\% podmiotów w 2003 i 44\% podmiotów w 2009 r. To samo dotyczy wyższych przedziałów płac. Dane te świadczą o przesuwaniu się w kolejnych latach po akcesji większej liczby przedsiębiorstw do wyższych przedziałów płacowych i zwiększającej się prawostronnej skośności rozkładu wynagrodzeń.

O ile w roku 2003 najwyższy poziom koncentracji zarobków charakteryzował przedsiębiorstwa kompleksu energetycznego, to w sześć lat później płace w tej sekcji stały się zdecydowania bardziej zdywersyfikowane. W roku 2003 przedsiębiorstwa przemysłowe zajmowały w większości przedział zbliżony do średniej płacy (ok. 34,8\% podmiotów). Sześć lat później przedziałem płac skupiającym największą zbiorowość przedsiębiorstw tej sekcji było $4-5$ tys. $(29,5 \%)$.

Trwałą cechą zróżnicowania płac z uwzględnieniem sekcji jest ich bardzo wysoka dywersyfikacja $\mathrm{w}$ przedsiębiorstwach handlowych. Jeszcze w roku 2009 płacę poniżej 3 tys. uzyskiwało aż 17\% tych podmiotów i tyle samo wynagrodzenie powyżej 8 tys. zł.

$\mathrm{W}$ przedziale płac relatywnie niskich mieściły się przede wszystkim przedsiębiorstwa prywatne $\mathrm{z}$ większościowym i pełnym udziałem kapitału krajowego. W roku 2003 przedział płac do 3 tys. zł w zdecydowanej większości zajmowany był właśnie przez te podmioty (26\% ich ogółu na Liście wobec dla przykładu tylko 2,6\% spółek Skarbu Państwa). Przedział płac tych podmiotów jest wyraźnie lewostronnie skośny.

Zajęcie przez spółki z dominującym we własności kapitałem zagranicznym pozycji lidera w rankingu opartym na średniej płacy odbyło się w sytuacji koncentracji większości z nich w roku 2009 w przedziale płac wysokich (38\% tych podmiotów mieściło się w przedziale płac 5-7 tys. zł).

Relatywnie wysoko opłacały swoich pracowników spółki Skarbu Państwa. W roku 2003 w około $43 \%$ spośród nich płaca przeciętna kształtowała się na poziomie wyższym aniżeli wyznaczony granicami określającymi przedział zbliżony do średniej. Sześć lat później przedziałem, w którym lokowało się ich największe przedstawicielstwo, był przedział od 5 do 6 tys. zł, a więc zdecydowanie przekraczający średnią płacę.

\section{PIONOWE ROZPIĘTOŚCI W PŁACACH}

W porównaniu z rokiem 2003 nie odnotowano istotnych zmian w pionowych rozpiętościach płac, choć wciąż są one znaczące (tabela 10). W roku 
2009 daje się wręcz zaobserwować znaczne zmniejszenie relacji płacy przedsiębiorstw najwyżej i najniżej opłacających swoich pracowników. Różnica między najwyższą a najniższą płacą stanowiła w tym roku o 50 p.p. niższy odsetek średniej płacy niż w roku 2007. Zmniejszenie się pionowych rozpiętości w roku 2009 dotyczyło tak zróżnicowania płac według sekcji, jak i w przekroju według form własności. Średnia płaca w przedsiębiorstwach reprezentujących formę własności, w których jest ona najwyższa, odniesiona do średniej płacy w ogóle przedsiębiorstw z Listy 500 w roku 2009 w porównaniu z rokiem 2003 zmniejszyła się o prawie 9 p.p. Ponieważ fakt ten dotyczy jednego roku i zdaje się wynikać $\mathrm{z}$ wyhamowywania płac $\mathrm{w}$ okresie spowalniania koniunktury zwłaszcza przez przedsiębiorstwa prywatne krajowe, wysuwanie na jego podstawie wniosku o zmniejszaniu się rozpiętości płac byłoby przedwczesne.

Tabela 10. Pionowe rozpiętości wynagrodzeń $\mathrm{w}$ przedsiębiorstwach z Listy 500 w latach 2003, 2005, 2007, 2009

\begin{tabular}{|c|c|c|c|c|c|c|c|c|}
\hline Lata & $\begin{array}{c}\text { Średnia } \\
\text { płaca dla } \\
\text { całej } \\
\text { zbioro- } \\
\text { wości (zł) }\end{array}$ & $\begin{array}{c}\text { Średnia płaca } \\
\text { w 10 najlepiej } \\
\text { płacacych } \\
\text { przedsiębior- } \\
\text { stwach (zł) }\end{array}$ & $\begin{array}{c}\text { Średnia płaca } \\
\text { w 10 najgo- } \\
\text { rzej płacacych } \\
\text { przedsiębior- } \\
\text { stwach (zł) }\end{array}$ & $\begin{array}{c}(2):(3) \\
(\%)\end{array}$ & $\begin{array}{c}(2):(1) \\
(\%)\end{array}$ & $\begin{array}{c}(3):(1) \\
(\%)\end{array}$ & $\begin{array}{c}(2)-(3)) /(1) \\
(\%)\end{array}$ & $\begin{array}{c}\text { Współczyn- } \\
\text { nik zmien- } \\
\text { ności dla } \\
\text { całej zbio- } \\
\text { rowości }\end{array}$ \\
\cline { 2 - 9 } & $(1)$ & $(2)$ & $(3)$ & $(4)$ & $(5)$ & $(6)$ & $(7)$ & $(8)$ \\
\hline 2003 & 3369 & 11612 & 1592 & 729,4 & 344,7 & 47,3 & 297,4 & 0,7 \\
2005 & 3569 & 11089 & 1339 & 828,2 & 310,7 & 37,5 & 273,2 & 0,65 \\
2007 & 4025 & 14728 & 1663 & 885,6 & 365,9 & 41,3 & 324,6 & 0,82 \\
2009 & 4844 & 11592 & 1834 & 632,1 & 239,3 & 37,9 & 201,9 & 0,65 \\
\hline
\end{tabular}

Źródło: jak w tabeli 1.

\section{PODSUMOWANIE}

Po wejściu do UE giganty polskiej gospodarki odnotowały istotny wzrost wynagrodzeń. Wzrost ten dokonał się zwłaszcza w ostatnich latach i choć towarzyszył mu także wzrost wyników finansowych, to jednak ten ostatni był znacznie mniej dynamiczny niż w rok po akcesji. Duże przedsiębiorstwa w Polsce nie uległy spodziewanej presji na wzrost płac bezpośrednio po wstąpieniu do UE. Sekcją wiodącą w rankingu średniej płacy w roku 2003 i 2005 było górnictwo. Boom budowlany połączony z migracją pracowników budowlanych wywindował w roku 2007 płace w sekcji budownictwo do maksymalnego w badanym okresie poziomu. Chociaż w roku 2009 płace w budownictwie były niższe, to i tak sekcja ta utrzymała pozycję lidera. 
O ile w latach wcześniejszych pod względem poziomu przeciętnych wynagrodzeń wiodącą pozycję zajmowały podmioty sektora prywatnego, to już od 2007 roku miejsce to zajęły przedsiębiorstwa publiczne, w tym spółki Skarbu Państwa. Choć pozycja lidera, gdy chodzi o płace, przypada przedsiębiorstwom zagranicznym, to jednak w spółkach Skarbu Państwa wynagrodzenia są prawie tożsame $\mathrm{z}$ pierwszymi. $\mathrm{O}$ ile $\mathrm{w}$ pierwszym $\mathrm{z}$ wymienionych podmiotów wysokie płace wynikają $\mathrm{z}$ dobrych wyników finansowych, o tyle wysokie płace w drugim nie mają żadnego uzasadnienia w wynikach. Jest to dla gospodarki groźne.

Trzeba podkreślić, że podmioty sektora prywatnego w obliczu dekoniunktury stają się zdecydowanie bardziej rozważne w swoich decyzjach płacowych.

\section{LITERATURA}

Lista 500, „Rzeczpospolita”, kwiecień 2004. Lista 500, „Rzeczpospolita”, kwiecień 2006. Lista 500, „Rzeczpospolita”, kwiecień 2008. Lista 500, „Rzeczpospolita”, kwiecień 2010.

\section{REMUNERATION OF GIANTS OF THE POLISH ECONOMY AFTER ACCESSION TO THE UE}

$\mathrm{Abstract}$. The article contains results of analysis of changes which took place in the sphere of pays, in this their connecting with the level the profitability of the largest enterprises in Poland after the accession to the UE. Trends concerning structural changes are being defined including the diameter according to section, forms of the property, participation of foreign capital.

$\mathrm{K} \mathrm{e} \mathrm{y} \mathrm{w} \mathrm{o} \mathrm{r} \mathrm{d} \mathrm{s} \mathrm{:} \mathrm{pay,} \mathrm{remuneration,} \mathrm{relations} \mathrm{of} \mathrm{pays,} \mathrm{diversifying} \mathrm{pays,} \mathrm{economic}$ results, accession to the EU. 